Performance of Ornamental Plants in

\section{Alternative Organic Growing Media Amended with Increasing Rates of Expanded Shale}

\author{
John J. Sloan ${ }^{1,4,6}$, Raul I. Cabrera ${ }^{1,4}$, Peter A.Y. Ampim ${ }^{1,5}$, \\ Steve A. George ${ }^{2}$, and Wayne A. Mackay ${ }^{3}$
}

ADDITIONAL INDEX WORDs. substrates, peatmoss, biosolids, compost, cottonseed hulls

SUMMARY. Organic and inorganic amendments are often used to improve chemical and physical properties of soils. The objective of this study was to determine how the inclusion of light-weight expanded shale in various organic matter blends would affect plant performance. Four basic blends of organic growing media were prepared using traditional or alternative organic materials: 1) $75 \%$ pine bark (PB) + 25\% sphagnum peatmoss (PM), 2) 50\% PB + 50\% wastewater biosolids (BS), 3) $100 \%$ municipal yard waste compost (compost), and 4 ) $65 \% \mathrm{~PB}+35 \%$ cottonseed hulls $(\mathrm{CH})$. Light-weight expanded shale was then blended with each of these mixtures at rates of $0 \%, 15 \%, 30 \%$, and $60 \%(\mathrm{v} / \mathrm{v})$. Vinca (Catharanthus roseus), verbena (Verbena bybrida), and shantung maple (Acer truncatum) were planted into the growing media after they were transferred into greenhouse pots. Vinca growth was monitored for 3 months before harvesting aboveground plant tissue to determine total biomass yield and elemental composition. Verbena growth was monitored for 6 months, during which time aboveground plant tissue was harvested twice to determine total biomass yield. Additionally, aboveground vinca plant tissue was analyzed for nutrients and heavy metal concentrations. In the absence of expanded shale, verbena and shantung maple trees produced more aboveground biomass in the 50-PB/50-BS blends, whereas vinca grew more biomass in the pure compost blends. Inclusion of expanded shale in the various organic matter blends generally had a negative effect on plant growth, with the exception of shantung maple growth in the $65-\mathrm{PB} / 35-\mathrm{CH}$ blend. Reduced plant growth was probably due to a lower concentration of nutrients in the growing media. Macro- and micronutrient uptake was generally reduced by addition of expanded shale to the organic growing media. Results suggest that organic materials that have been stabilized through prior decomposition, such as compost or PM, are safe and reliable growing media, but expanded shale offers few benefits to a container growing medium except in cases where additional porosity is needed.

A variety of organic and inorganic products are sold at nurseries and box stores around the United States for use directly as plant growth substrates in raised beds and planters, or as soil amendments. In reality, many of the soil amendment products function more as plant growth substrates when the amount added to the soil, combined with the difficulty of adequately incorporating the product into the soil, creates a highly modified rooting

\footnotetext{
${ }^{1}$ Texas AgriLife Research, 17360 Coit Road, Dallas, TX 75075

${ }^{2}$ Professor, Texas AgriLife Extension Service, 17360 Coit Road, Dallas, TX 75075

${ }^{3}$ Professor and Center Director, University of Florida, IFAS, MREC 2725 South Binion Road, Apopka, FL 32703

${ }^{4}$ Associate Professor

${ }^{5}$ Postdoctoral Research Associate

${ }^{6}$ Corresponding author. E-mail: j-sloan@tamu.edu.
}

zone. The difficulty with adequate incorporation is magnified when the soil amendments are added to claytextured soils, which are inherently more difficult to till than sandy- or loam-textured soils. Most of these products traditionally use pine bark (PB) and peatmoss (PM) as their major ingredients. Short-term nitrogen $(\mathrm{N})$ deficiencies due to a high carbon:nitrogen $(\mathrm{C}: \mathrm{N})$ ratio are frequently observed when these products are used as a growing medium or as a soil amendment (Gruda et al., 2000; Jim, 1996; Sloan et al., 2002).

Expanded shale is a lightweight, porous aggregate made by heating crushed mined shale to $>1200{ }^{\circ} \mathrm{C}$ in a rotary kiln followed by screening to isolate various size fractions. Due to its porous nature, expanded shale will absorb up to $25 \%$ water (w/w) in $24 \mathrm{~h}$ and up to $35 \%$ water $(\mathrm{w} / \mathrm{w})$ over a 4- to 6-d period (Sloan et al., 2000). Because expanded shale will absorb water, soluble nutrients can diffuse into the expanded shale's inner network of interconnected pores where they are temporarily protected from leaching. Nutrients can later diffuse out of those pores when the expanded shale aggregate is again surrounded by water (Sloan et al., 2000). This property could make expanded shale a beneficial ingredient of growing media, especially when combined with decomposable organic materials such as compost and biosolids (BS). Because expanded shale can absorb water and soluble nutrients, it is possible that it would absorb nutrients released from mineralized organic matter and extend the time they are retained in the plant rooting zone. Sloan et al. (2002) found that 3- to 6-mm-diameter expanded shale blended into a clay-textured soil at a 50:50 ratio had positive effects on the performance of annual flowers in terms of root growth and percentage flower cover.

Whereas traditional nursery growing media contain predominantly $\mathrm{PM}$ and aged $\mathrm{PB}$, there are other potentially suitable organic

\begin{tabular}{llll}
\hline $\begin{array}{l}\text { Units } \\
\begin{array}{l}\text { To convert U.S. to SI, } \\
\text { multiply by }\end{array}\end{array}$ & U.S. unit & SI unit & $\begin{array}{l}\text { To convert SI to U.S., } \\
\text { multiply by }\end{array}$ \\
\hline 10 & $\%$ & $\mathrm{~g} \cdot \mathrm{kg}^{-1}$ & 0.1 \\
0.3048 & $\mathrm{ft}$ & $\mathrm{m}$ & 3.2808 \\
2.54 & inch $(\mathrm{es})$ & $\mathrm{cm}$ & 0.3937 \\
25.4 & inch $(\mathrm{es})$ & $\mathrm{mm}$ & 0.0394 \\
16.3871 & inch & $\mathrm{cm}^{3}$ & 0.0610 \\
0.5933 & $\mathrm{lb} / \mathrm{yard}^{3}$ & $\mathrm{~kg} \cdot \mathrm{m}^{-3}$ & 1.6856 \\
1 & $\mathrm{meq} / 100 \mathrm{~g}$ & $\mathrm{cmol} \cdot \mathrm{kg}^{-1}$ & 1 \\
1 & micron & $\mu \mathrm{m}$ & 1 \\
1 & $\mathrm{mmho} / \mathrm{cm}$ & $\mathrm{dS} \cdot \mathrm{m}^{-1}$ & 1 \\
28.3495 & $\mathrm{oz}$ & $\mathrm{g}$ & 0.0353 \\
1 & $\mathrm{ppm}$ & $\mathrm{mg} \cdot \mathrm{kg}^{-1}$ & 1 \\
$\left({ }^{\circ} \mathrm{F}-32\right) \div 1.8$ & ${ }^{\circ} \mathrm{F}$ & ${ }^{\circ} \mathrm{C}$ & $\left(1.8 \times{ }^{\circ} \mathrm{C}\right)+32$ \\
\end{tabular}


materials that may be more readily available in certain urban areas (Fain et al., 2008; Hernández-Apaolaza et al., 2005; Jim, 1996; Marble, et al., 2008). Many municipalities produce compost from their residential yard waste or municipal solid waste to divert those organic residuals away from municipal landfills (Glenn and Block, 1999; Steuteville, 1996). Wastewater BS is another nutrientrich organic material that is readily available in urban areas, although there is likely to be some public resistance to its use in urban landscapes (Ozores-Hampton and Peach, 2002).

The objectives of this study were to evaluate non-traditional organic materials as potential ingredients in growing media and to determine the effect of expanded shale on those organic matter blends.

\section{Materials and methods}

PREPARATION OF GROWING MEDIA. Organic materials used in the preparation of the experimental growth media are listed in Table 1 along with their total $\mathrm{N}$ and $\mathrm{C}$ contents, which were determined by combustion analysis using an Elementar Vario Macro $\mathrm{C} / \mathrm{N}$ analyzer (Elementar Analysensysteme, Hanau, Germany). The traditional growing medium contained sphagnum PM (SunGro Horticulture, Bellevue, WA) and aged PB (Calloway's Nurseries, Fort Worth, TX). The alternative blends used non-traditional materials, including municipal yard waste compost (compost), lime-stabilized wastewater BS (City of Fort Worth, TX) and cottonseed hulls $(\mathrm{CH})$ (Martindale Feed Mill, Valley View, TX). No additional processing of individual ingredients was made before preparing the experimental media.

The first step in preparing the experimental growth media was to mix the organic ingredients to create four preliminary organic blends (Table 2). Mixing ratios were based on volume. To gauge the initial fertility level of each preliminary blend before the addition of expanded shale, a representative sample was collected and extracted with deionized water on a reciprocal shaker using a $1: 5$ sample-to-water ratio and a 30 -min equilibration time. Nitrate- $\mathrm{N}\left(\mathrm{NO}_{3}-\mathrm{N}\right)$ content was measured in the filtered extract with a combination ion-selective electrode (Thomas Scientific, Swedesboro, $\mathrm{NJ}$ ), $\mathrm{pH}$ with a combination glass/reference electrode (Nova Analytics, Woburn, MA), and electrical conductivity (EC) with a dip-type platinum conductivity cell (Fisher Scientific, Pittsburgh). Expanded shale (TXI True Grow, Dallas, TX) was then added to each of the preliminary organic matter blends at rates of $0 \%$, $15 \%, 30 \%$, and $60 \%$ to create 16 experimental growth media. The expanded shale used in this study had a particle size range of 3 to $6 \mathrm{~mm}$. The high temperature used to manufacture expanded shale created an alkaline material $(\mathrm{pH} 8.3)$ due to the

Table 1. Total nitrogen (N) and carbon (C) content of organic materials used to prepare four experimental growing media.

\begin{tabular}{lccc}
\hline Organic material & $\begin{array}{c}\mathbf{N} \\
\left(\mathrm{g} \cdot \mathbf{k g}^{-1}\right)^{\mathbf{z}}\end{array}$ & $\begin{array}{c}\mathbf{C} \\
\left(\mathrm{g} \cdot \mathbf{k g}^{-1}\right)\end{array}$ & $\begin{array}{c}\mathrm{C}: \mathbf{N} \\
(\text { ratio })\end{array}$ \\
\hline Aged pine bark & 3.3 & 459 & 126 \\
Sphagnum peatmoss & 8.3 & 472 & 57 \\
Municipal yard waste compost & 7.2 & 114 & 16 \\
Biosolids & 19.7 & 190 & 10 \\
Cottonseed hulls & 4.9 & 473 & 97 \\
\hline
\end{tabular}

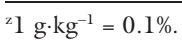

formation of calcium $(\mathrm{Ca})$ and magnesium $(\mathrm{Mg})$ oxides on the aggregate surfaces. The cation exchange capacity (CEC) was negligible $(2.8$ $\left.\mathrm{cmol} \cdot \mathrm{kg}^{-1}\right)$.

Ingredients were mixed in a portable rotary cement mixer and were then transferred to three sets of greenhouse pots. The size of the containers depended on the species to be grown. The first set of standard 6-inch-diameter round pots was direct seeded with the annual flower, vinca. Each treatment was replicated four times with each replicate consisting of a group of five individual 6-inch-diameter pots. Pots were arranged on $5 \times 10-\mathrm{ft}$ greenhouse benches in a completely randomized block design (CRBD) where a greenhouse bench represented one block. Three vinca seeds were planted into each pot. Germination ranged from one to three plants per pot. All pots were thinned to one plant per plot following emergence of the first true leaves.

A second set of standard \#l greenhouse containers (American Association of Nurserymen, 1996) was planted with rooted cuttings (one per pot) from the perennial flower, 'Blue Princess' verbena. The verbena cuttings were collected from established beds and rooted in $100 \%$ perlite medium under intermittent mist controlled by electronic leaf. Each treatment was replicated four times with each replicate consisting of four individual \# 1 pots. Pots were arranged on greenhouse benches in a CRBD where a greenhouse bench represented one block.

A third set of standard \#l greenhouse containers was planted with bare-rooted 1-year-old seedlings of shantung maple. Each treatment was replicated four times with each replicate consisting of four individual \#1 greenhouse containers. Pots were arranged on greenhouse benches in a CRBD where a greenhouse bench

Table 2. Types and ratios of organic ingredients in four experimental growing media, as well as $\mathrm{pH}$, electrical conductivity (EC), and nitrate-nitrogen $\left(\mathrm{NO}_{3}-\mathrm{N}\right)$ contents of each blend.

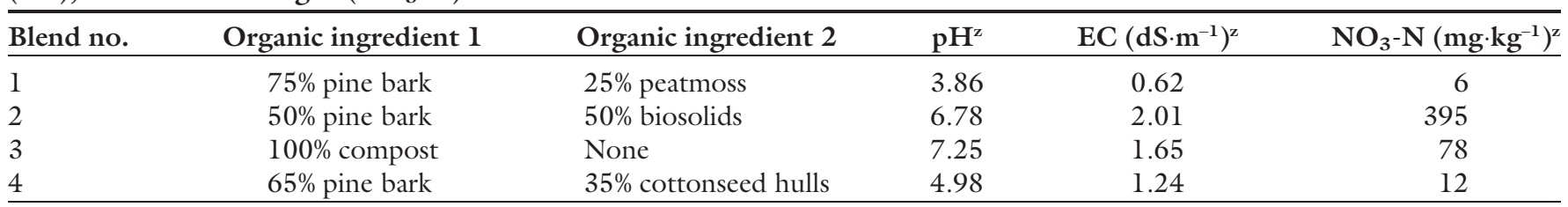

${ }^{2}$ Measured in a 1:5 extract with deionized water; $1 \mathrm{dS} \cdot \mathrm{m}^{-1}=1 \mathrm{mmho} / \mathrm{cm}, 1 \mathrm{mg} \cdot \mathrm{kg}^{-1}=1 \mathrm{ppm}$. 
represented one block. The plants selected for evaluating the experimental growing media represent those that might be selected by homeowners, nurseries, and other users of growing media.

Shortly after planting, I teaspoon $(4.5 \mathrm{~g})$ of $14 \mathrm{~N}-6.1 \mathrm{P}-11.6 \mathrm{~K}$ controlled-release fertilizer (Osmocote ${ }^{\circledR}$ 14-14-14; Scotts, Marysville, $\mathrm{OH})$ was applied to each 6-inchdiameter container and 2 teaspoons $(9 \mathrm{~g})$ to each \#l greenhouse container to promote the establishment of plants. With average daily temperature in the greenhouse ranging from 22 to $30^{\circ} \mathrm{C}$, the longevity of this formulation of controlled-release fertilizer was $\approx 2$ to 3 months. After the initial application of controlled-release fertilizer, fertility levels were allowed to decline throughout the study by withholding additional fertilization so that the inherent nutrientsupplying capacity of each mixture could be evaluated. Each set of pots was watered individually based on visual and tactual observations of water content in the upper 2 inches of the growth medium. Irrigation frequency ranged from once per day in the summer months to three times per week during winter months. Water was applied with a hand-held water wand and all pots within a set received the same amount of water, which was targeted to deliver an average 25\% leaching fraction.

Physical properties of MIXES. Physical properties were measured using a $1000-\mathrm{cm}^{3}$ PVC cylinder with a perforated, removable flat bottom. The cylinder was filled with the growing medium and tapped three times on the bench top surface, followed by addition of more growing medium and additional tapping. This was repeated until no additional settling occurred. The cylinders plus contents were then placed in tubs that were slowly filled with water so that the growing media would absorb water from the bottom up, allowing trapped air to escape. Water was added to the tub until the level outside the cylinders was even with the surface of the growing media in the cylinder. After $1 \mathrm{~h}$, the holes on the bottom of the cylinder were covered to prevent drainage while the cylinder was removed from the tub. The cylinder was placed on top of a funnel which drained into a collection vessel. The holes were uncovered and water was allowed to drain from the growing media for $24 \mathrm{~h}$. The volume of water drained from the growing media was measured and that value was used to calculate total percentage of pore space $(\mathrm{v} / \mathrm{v})$ of the growing media by dividing the volume of drainage water by the cylinder volume. The cylinder plus contents were weighed and then dried at $60^{\circ} \mathrm{C}$ until a constant weight was obtained. Bulk density was calculated by dividing the oven dry weight of the growing media by the cylinder volume $\left(1000 \mathrm{~cm}^{3}\right)$. Container capacity water content $(\mathrm{v} / \mathrm{v})$ was equal to the volume of water in the growing media (assuming $\mathrm{l} \mathrm{g}=\mathrm{l} \mathrm{cm}^{3}$ water) at the end of the 24-h drainage period divided by the cylinder volume.

Plant measurements. Plants were grown in a glasshouse for various periods of time that were determined by the plant species. Vinca seeds were planted 1 June and the aboveground portions of the plants were harvested 12 weeks later during the last week of August. Plant growth data collected for vinca plants included total aboveground biomass and tissue concentrations of $\mathrm{N}$, phosphorus $(\mathrm{P})$, potassium $(\mathrm{K}), \mathrm{Ca}, \mathrm{Mg}$, chromium $(\mathrm{Cr})$, copper $(\mathrm{Cu})$, nickel $(\mathrm{Ni})$, and zinc $(\mathrm{Zn})$. During the experiment, some of the vinca plants exhibited chlorosis symptoms, so the plants were visually rated for chlorosis using a scale that ranged from 0 for a completely healthy plant to 5 for a plant with $100 \%$ of the foliage exhibiting yellow color.

Verbena cuttings were transplanted into the experimental growing media on 21 June. Eight weeks later, on 16 Aug., all plants were trimmed to a uniform $5 \mathrm{~cm}$ height and subsequent growth measurements were collected at 16,32 , and $45 \mathrm{~d}$ after that pruning. Plant growth measurements consisted of stem length and flower counts. Aboveground biomass was collected 46 d after trimming stems to a $5 \mathrm{~cm}$ length. Verbena regrowth was harvested in a similar fashion $66 \mathrm{~d}$ after the first harvest.

Uniform bare-rooted shantung maples seedlings were transplanted into the experimental growth media during the first week of June. Plant growth measurements began immediately and continued biweekly through the first week of August.
Shantung maples were monitored, over a 10 -week period, for plant height (base to crown), plant width at two consistent perpendicular orientations, and stem thickness at a height $2.5 \mathrm{~cm}$ above the base.

Aboveground plant biomass was harvested from vinca and verbena plants, but not from the shantung maple trees. Vinca and verbena plants were clipped at heights $1-\mathrm{cm}$ above the surface of the growing medium, first washed in tap water and then rinsed twice in deionized water. Plants were oven-dried at $60{ }^{\circ} \mathrm{C}$ to determine biomass on a dry weight basis. Plant tissue was ground using a Wiley mill to pass a $1-\mathrm{mm}$ sieve. Total Kjeldahl $\mathrm{N}$ was measured by digesting the plant samples in concentrated sulfuric acid followed by steam distillation (Bremner, 1996). Total P, K, Ca, Mg, Zn, Cu, Cr, and Ni were measured by dry-ashing samples in a muffle furnace at $5500^{\circ} \mathrm{C}$ and dissolving the ash in $2.5 \mathrm{M}$ hydrochloric acid $(\mathrm{HCl})$ before diluting to volume with deionized water. Total $\mathrm{P}$ was measured using the ascorbic acid colorimetric method (Olsen and Sommers, 1982), and the remaining minerals were measured by flame atomic absorption spectrophotometry (240FS; Varian, Palo Alto, CA). In subsequent discussion, tissue analysis results are shown only for vinca, as in general, the results for verbena were similar.

\section{Results and discussion Physical properties of growing media}

BulK DENSITY. Bulk densities of the four blends of organic materials without expanded shale were 243 $\mathrm{kg} \cdot \mathrm{m}^{-3}$ for the $75-\mathrm{PB} / 25-\mathrm{PM}$ blend, $484 \mathrm{~kg} \cdot \mathrm{m}^{-3}$ for the $50-\mathrm{PB} / 50-\mathrm{BS}$ blend, $678 \mathrm{~kg} \cdot \mathrm{m}^{-3}$ for the compost, and $207 \mathrm{~kg} \cdot \mathrm{m}^{-3}$ for the $65-\mathrm{PB} / 35-$ $\mathrm{CH}$ blend (Table 3). Generally, organic materials that were coarser in texture and had not passed through a period of decomposition $(\mathrm{PB}$ and $\mathrm{CH}$ ) had lower bulk densities than those organic materials that had passed through a period of aerobic (compost) or anaerobic (BS) decomposition. Adding expanded shale to the organic growing media increased their bulk densities. The biggest increases occurred with the low bulk density blends (75-PB/25-PM and $65-\mathrm{PB} / 35-\mathrm{CH}$ ) and smaller increases 
Table 3. Bulk density, total porosity, and container capacity of four experimental growing media containing $75 \%$ pine bark (PB) + 25\% peatmoss (PM), 50\% PB + 50\% biosolids (BS), 100\% municipal yard waste compost (compost), or $65 \%$ PB $+35 \%$ cottonseed hulls $(\mathrm{CH})$ mixed with $0 \%, 15 \%, 30 \%$, or $60 \%$ expanded shale $(\mathrm{v} / \mathrm{v})$.

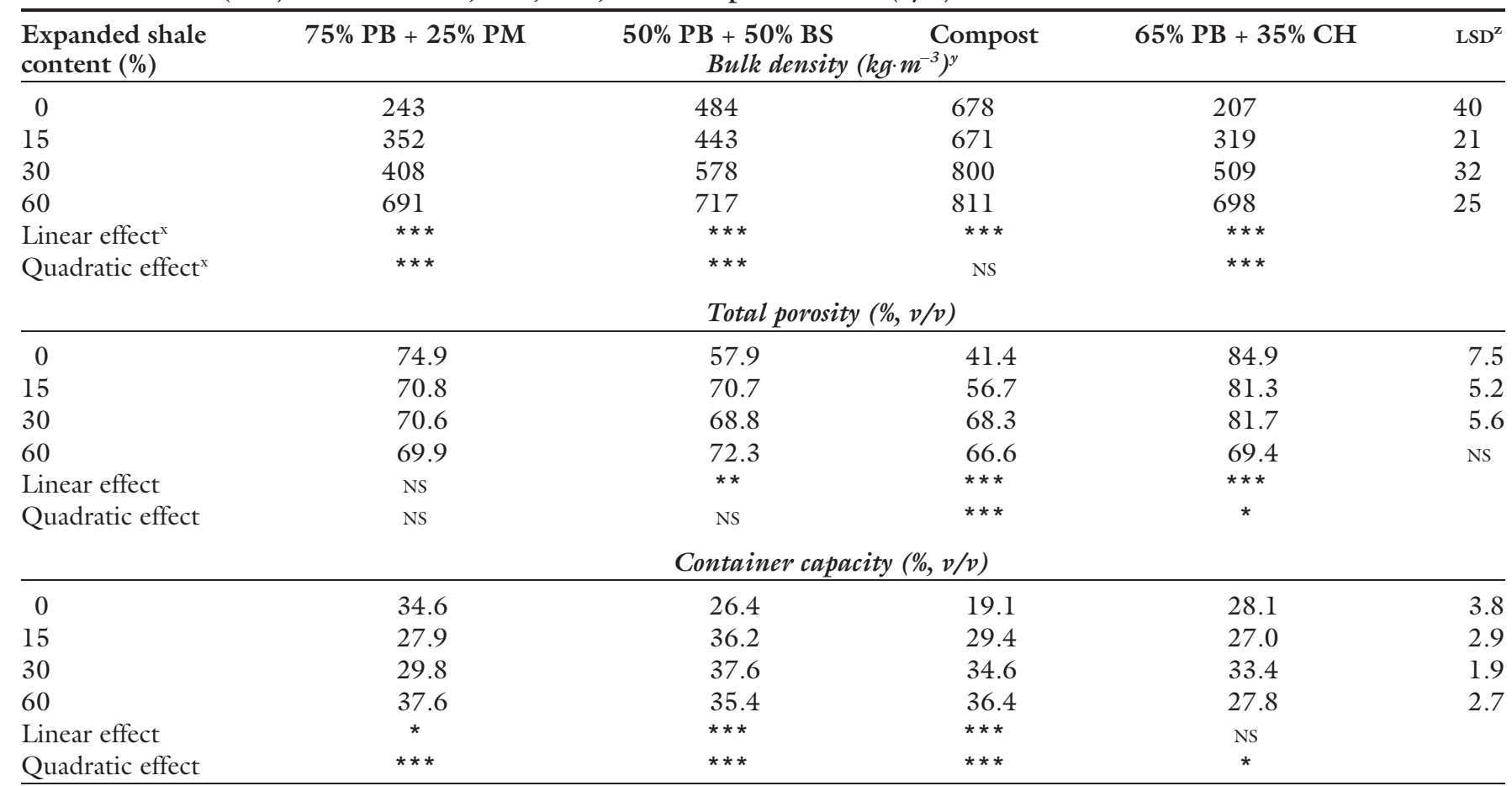

${ }^{\text {z}}$ Fisher's least significant difference test at $P<0.05(\mathrm{n}=4)$.

${ }^{\mathrm{y}} \mathrm{lg} \cdot \mathrm{m}^{-3}=1.6856 \mathrm{lb} / \mathrm{yard}^{3}$.

${ }^{x}$ Linear and quadratic effects of expanded shale content on dependent variables were tested via single-df orthogonal contrasts using PROC GLM of SAS (v. 9.1; SAS Institute, Cary, NC); completely randomized block design $(\mathrm{n}=4)$.

$\mathrm{NS},{ }^{*}, * *$, and ${ }^{* *}$ indicate not significant and significant at the $0.05,0.01$, or 0.001 level of probability, respectively $(\mathrm{n}=16)$.

were observed for the higher density blends (50-PB /50-BS and compost). The larger increase in bulk density for the $75-\mathrm{PB} / 25-\mathrm{PM}$ and $65-\mathrm{PB} / 35$ $\mathrm{CH}$ blends may also be attributed to their moisture content at the time they were mixed with expanded shale. Peatmoss and $\mathrm{CH}$ were very dry at the time of mixing, whereas as the compost, and especially the BS, were considerably wetter. Bilderback et al. (2005) reported that mixing dry components allowed particles to fit together more closely, which resulted in a denser blend than when all or some of the ingredients were wet. At the $60 \%$ rate of expanded shale, bulk density was significantly greater for the compost blend $\left(811 \mathrm{~kg} \cdot \mathrm{m}^{-3}\right)$, but was similar for the other three blends (691-717 $\left.\mathrm{kg} \cdot \mathrm{m}^{-3}\right)$. For comparison purposes, most retail potting mixes have bulk densities in the range of 190 to $700 \mathrm{~kg} \cdot \mathrm{m}^{-3}$ (Bilderback et al., 2005). Therefore, adding expanded shale to the basic organic growing media increased their bulk densities to levels that were less than optimum for retail potting mixes. However, higher bulk densities would not be a problem or critical consideration if the growing media were used outdoors in raised beds or planters.

Total porosity. Total porosities for the four blends of organic materials without expanded shale were $74.9 \%$ for the $75-\mathrm{PB} / 25-\mathrm{PM}$ blend, $57.9 \%$ for the $50-\mathrm{PB} / 50-\mathrm{BS}$ blend, $41.4 \%$ for the compost, and $84.9 \%$ for the $65-\mathrm{PB} / 35-\mathrm{CH}$ blend (Table 3 ). Blends with high porosities corresponded to those with low bulk densities. Expanded shale had no effect or slightly decreased the porosity of growing media that had high initial porosities $(75-\mathrm{PB} / 25-\mathrm{PM}$ and $65-\mathrm{PB} / 35-\mathrm{CH})$, but increased the porosity of blends that had low initial total porosities $(50-\mathrm{PB} / 50-\mathrm{BS}$ and compost). Expanded shale had the largest effect on compost, and without its addition, the total porosity of compost $(41.4 \%)$ was much lower than an optimal total pore space of $85 \%$ for container growing media (Bunt, 1988). Adding expanded shale to the compost increased its total porosity to a more optimal level (50\%-85\%) (Bilderback et al., 2005). At the $60 \%$ rate of expanded shale, all growing media had similar total porosities of $\approx 70 \%$.

CONTAINer CAPACITY WATER CONTENT. Volumetric container capacities for the four blends of organic materials without expanded shale were $34.6 \%$ for the $75-\mathrm{PB} / 25-\mathrm{PM}$ blend, $26.4 \%$ for the $50-\mathrm{PB} / 50-\mathrm{BS}$ blend, $19.1 \%$ for the compost, and $28.1 \%$ for the $65-\mathrm{PB} / 35-\mathrm{CH}$ blend (Table 3 ). For comparison purposes, the typical container capacity of most retail potting mixes is in the range of $45 \%$ to $65 \%$ (Bilderback et al., 2005). Expanded shale had little effect on the container capacity water contents of the $75-\mathrm{PB} / 25-\mathrm{PM}$ and $65-\mathrm{PB} / 35$ $\mathrm{CH}$ blends, but increased the container capacity of the $50-\mathrm{PB} / 50-\mathrm{BS}$ and composts blends. At the 60\% expanded shale content, all growing media, except 65-PB/35-CH, had similar container capacity water contents that were primarily determined by the effect the expanded shale component had on the basic organic matter blends. The large 3- to 6-mm expanded shale particle size prevented the retention of significant amounts of water in the interaggregate pore space. 


\section{Plant growth}

VINCA. Vinca biomass was significantly decreased in media containing increasing amounts of expanded shale (Fig. 1). The response was most pronounced in the traditional 75$\mathrm{PB} / 25-\mathrm{PM}$ blend and the experimental 50-PB/50-BS blend. Rowe et al. (2006) also observed a decline in growth and performance of multiple plant species when the expanded slate content of their green roof growing medium was increased from $60 \%$ to $100 \%$. When blended with compost, the $15 \%$ and $30 \%$ rates of expanded shale did not negatively affect vinca biomass as much as they did for the 75-PB/25-PM and 50$\mathrm{PB} / 50$-BS blends, but the $60 \%$ rate of expanded shale had a large negative effect in all of these organic matter blends. In general, overall vinca growth was best in the compost blends, followed by the $75-\mathrm{PB} / 25$ $\mathrm{PM}$ blends and then the $50-\mathrm{PB} / 50$ BS blends. Vinca growth was so poor in the $65-\mathrm{PB} / 35-\mathrm{CH}$ blend that no growth data were collected. Sloan et al. (2002) observed that addition of $\mathrm{CH}$ directly to soil had a negative impact on the growth of annual flowers during the first year after application, but then increased growth during the second year.

VINCA CHLOROsIs. Foliage chlorosis may be attributed to a number of biotic factors such as diseases or insects, or abiotic factors such as poor water quality. When chlorosis appears first in the oldest foliage and then progresses to younger foliage, nitrogen deficiency is often a major contributing factor. In the case of our experimental growing media, the initial blends had a wide range of total $\mathrm{N}$ (Table 1) and $\mathrm{NO}_{3}-\mathrm{N}$ contents (Table 2). Also, the $\mathrm{C}: \mathrm{N}$ ratio of the PB (126), PM (57), and $\mathrm{CH}$ (97) ingredients suggest that $\mathrm{N}$ immobilization might occur. Therefore, we closely watch plant development for visual signs of $\mathrm{N}$ deficiency.

A general chlorosis in older foliage of some of the vinca plants became increasingly apparent as the experiment progressed. Therefore, chlorosis ratings were taken 2 weeks before the plants were harvested, which corresponded to a period when fertilizer nutrients applied to the growing media had probably been depleted by leaching and plant uptake. During the last month of growth, vinca plants probably relied primarily on the inherent fertility of the growing media, which was mostly a reflection of the organic ingredients in the blend. Plants growing in the $50-\mathrm{PB} / 50-\mathrm{BS}$ growing media showed no symptoms of chlorosis for any of the expanded shale rates (Table 4), probably due to an abundant supply of nutrients-especially nitrogen (Tables 1 and 3 ). The BS component of the $50-\mathrm{PB} / 50-\mathrm{BS}$ blend contained a relatively high total $\mathrm{N}$ content $\left(19.7 \mathrm{~g} \cdot \mathrm{kg}^{-1}\right)$, a low $\mathrm{C}: \mathrm{N}$ ratio of 10 (Table 1), and a high initial concentration of $\mathrm{NO}_{3}-\mathrm{N}$ (Table 2). Consequently, the $\mathrm{PB} /$ biosolids blends had high initial concentrations of plant available $\mathrm{N}$ and were able to sustain a significant supply of $\mathrm{N}$ and other nutrients due to mineralization of the BS organic matter. Analysis of vinca tissue at the end of the study confirmed that tissue $\mathrm{N}$ concentrations did not significantly decline with increasing proportions of expanded shale in the growing medium (Table 5).

Vinca growing in pure compost without expanded shale showed only slight chlorosis, but the level of chlorosis increased as the amount of expanded shale in the compost was increased (Table 4). The 75-PB/25PM blends showed the same trend in chlorosis as the compost, but the levels of chlorosis were much higher. A greater degree of vinca foliage chlorosis in the $75-\mathrm{PB} / 25$ PM blends compared with the

compost blends is consistent with the initial higher total $\mathrm{N}$ content and lower C: $\mathrm{N}$ ratio of compost (Table $\mathrm{l}$ ) as well as the higher $\mathrm{NO}_{3}-\mathrm{N}$ content of the compost blends (Table 2). Lower nutrient availability with increasing rates of expanded shale can be attributed to nutrient dilution. Expanded shale has no inherent fertility, thus for a given volume, as the amount of expanded shale in the blend increased, the amount of nutrient-supplying organic ingredients decreased. Therefore, the growing media that contained $60 \%$ expanded shale had a much lower supply of available nutrients than the same organic matter blends without expanded shale. Decreasing concentrations of plant $\mathrm{N}$ with increasing proportion of expanded shale in the 75-PB/25-PM and compost growing media were confirmed by tissue analysis at the end of the study (Table 5).

If these growing media were to be used as soil amendments, abundant nutrients would be beneficial because plants would respond favorably to the added nutrients. However, high concentrations of nutrients are not recommended when a growing media is used as a substrate for lowinput green roofs because the resulting lush growth would make the plant more susceptible to drought stress in the absence of irrigation (Getter and Rowe, 2006).

Verbena. Plants were harvested two times during the study to evaluate the ability of the experimental growing

Table 4. Vinca chlorosis ratings for three experimental growing media containing $75 \%$ pine bark $(\mathrm{PB})+\mathbf{2 5 \%}$ peatmoss $(\mathrm{PM}), \mathbf{5 0} \% \mathrm{~PB}+\mathbf{5 0} \%$ biosolids (BS), or $100 \%$ municipal yard waste compost (compost) mixed with $0 \%, 15 \%$, $30 \%$, or $60 \%$ expanded shale $(\mathrm{v} / \mathrm{v})$. Ratings range from 0 (no chlorosis) to 5 (yellowing of $100 \%$ of leaves).

\begin{tabular}{|c|c|c|c|}
\hline \multirow{2}{*}{$\begin{array}{l}\text { Expanded shale } \\
\text { content }(\%)\end{array}$} & \multicolumn{3}{|c|}{ Visual chlorosis rating $(0-5 \text { scale })^{\mathrm{z}}$} \\
\hline & $75 \% \mathrm{~PB}+\mathbf{2 5 \%} \mathrm{PM}$ & $50 \% \mathrm{~PB}+50 \% \mathrm{BS}$ & Compost \\
\hline 0 & 1.80 & 0 & 0.25 \\
\hline 15 & 1.15 & 0 & 0.35 \\
\hline 30 & 2.15 & 0 & 0.35 \\
\hline 60 & 4.05 & 0 & 0.75 \\
\hline Linear effect ${ }^{\mathrm{y}}$ & $* * *$ & NS & * \\
\hline Quadratic effect $\mathrm{t}^{\mathrm{y}}$ & *** & NS & NS \\
\hline
\end{tabular}

${ }^{2}$ Visual chlorosis readings pertain to the location and degree of yellowing in the aboveground foliage where $0=$ healthy plant with no yellowing of foliage, $1=$ mostly healthy plant with beginning signs of yellowing on oldest leaves, 2 = plant with yellowing of most of the oldest leaves, $3=$ plant with yellowing of all the oldest leaves and some of the newer leaves, $4=$ yellowing of most leaves on the plant, and $5=$ entire plant is yellow.

${ }^{y}$ Linear and quadratic effects of expanded shale content on dependent variables were tested via single-df orthogonal contrasts using PROC GLM of SAS (v. 9.1; SAS Institute, Cary, NC); completely randomized block design $(\mathrm{n}=$ 20).

$\mathrm{NS},{ }^{*}, * *$, and ${ }^{* *}$ indicate not significant and significant at the $0.05,0.01$, or 0.001 level of probability, respectively $(\mathrm{n}=20)$. 
Table 5. Concentrations of nitrogen $(\mathrm{N})$, phosphorus $(\mathrm{P})$, calcium $(\mathrm{Ca})$, and zinc $(\mathrm{Zn})$ in aboveground vinca foliage harvested from four experimental growing media containing $75 \%$ pine bark $(\mathrm{PB})+\mathbf{2 5 \%}$ peatmoss $(\mathrm{PM}), \mathbf{5 0} \% \mathrm{~PB}+\mathbf{5 0} \%$ biosolids (BS), or $100 \%$ municipal yard waste compost (compost) mixed with $0 \%, 15 \%, 30 \%$, or $60 \%$ expanded shale (v/v).

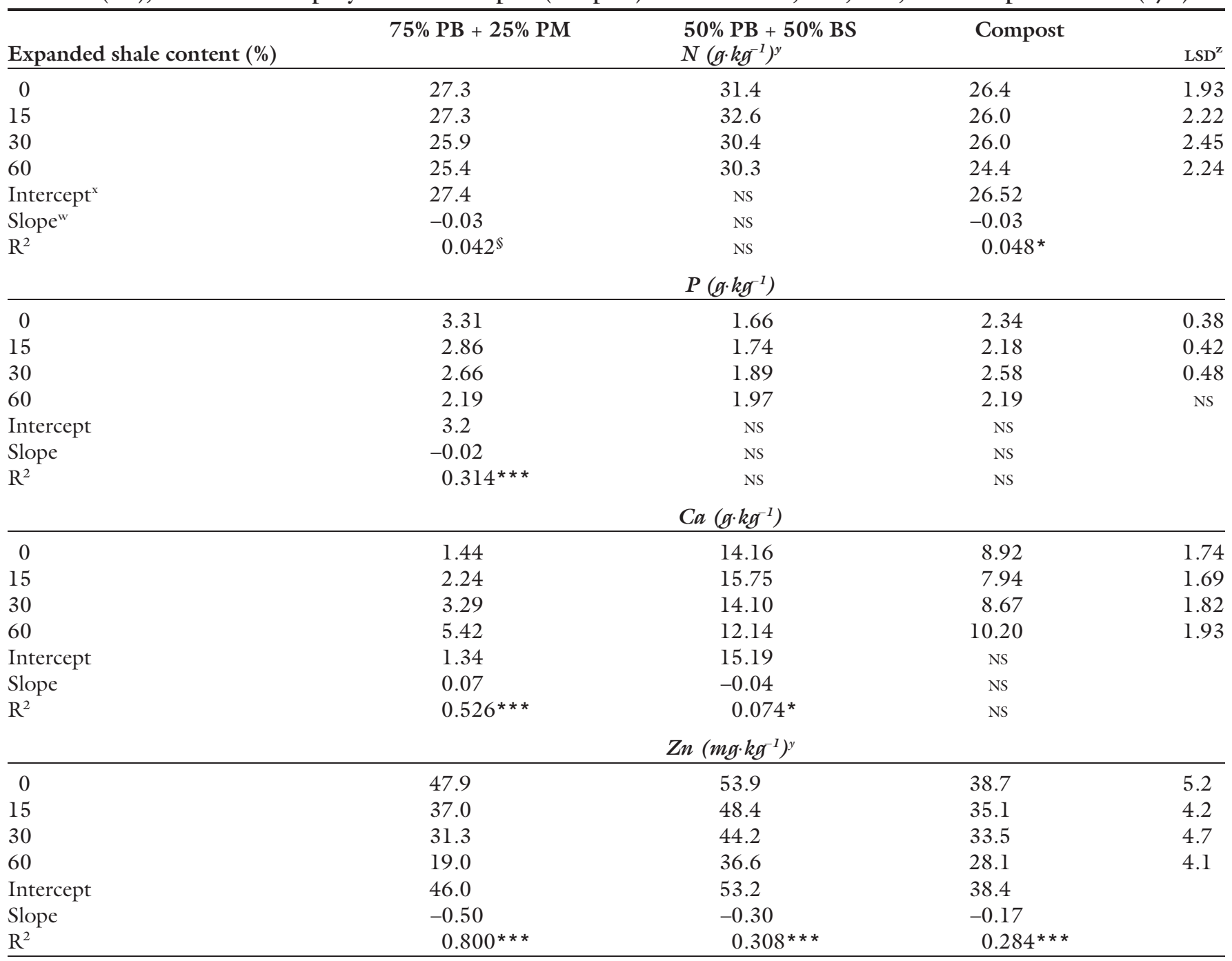

${ }^{\mathrm{z}}$ Fisher's least significant difference test at $P<0.05(\mathrm{n}=20)$.

'Tissue analysis performed on whole aboveground plant after grinding to pass through a $1-\mathrm{mm}(0.0394 \mathrm{inch}) \mathrm{sieve} ; \mathrm{l} \mathrm{g} \cdot \mathrm{kg}^{-1}=0.1 \% ; \mathrm{l} \mathrm{mg} \cdot \mathrm{kg}^{-1}=1 \mathrm{ppm}$.

'Intercept of the regression line for the expanded shale content versus nutrient concentration.

wSlope of the regression line for the expanded shale content versus nutrient concentration.

$\mathrm{NS}, \mathfrak{S},{ }^{*},{ }^{* *}$, and ${ }^{* * *}$ designates that the linear regression is not significant or is significant at the $0.10,0.05,0.01$, or 0.001 level of probability, respectively; $\mathrm{n}=20$

media to sustain plant growth beyond the initial establishment phase.

For the first harvest, verbena biomass production was generally similar for the $75-\mathrm{PB} / 25-\mathrm{PM}$, the compost, and the $50-\mathrm{PB} / 50-\mathrm{BS}$ blends, regardless of expanded shale content (Table 6). However, verbena biomass production in the 65-PB/ $35-\mathrm{CH}$ was less than half that of the other growing media.

Compared with the first harvest, biomass production for the second harvest was about half except for the 65-PB/35-CH blend (Table 6), which demonstrated similar biomass yields for both harvests. It is likely that the $\mathrm{CH}$ needed to be aged (i.e., partially decomposed) before being used in the growing media. Both $\mathrm{PB}$ and $\mathrm{CH}$ initially had high $\mathrm{C}: \mathrm{N}$ ratios (126 and 97, respectively), suggesting that a mixture of the these two ingredients would initially immobilize nitrogen and stunt plant growth.

Expanded shale had mixed effects on verbena growth in the growing media (Table 6). Verbena growth in the traditional $75-\mathrm{PB} / 25-\mathrm{PM}$ blend, the $50-\mathrm{PB} / 50$-BS blend, and the $65-\mathrm{PB} / 35-\mathrm{CH}$ blend was significantly reduced by the addition of expanded shale for the first and second harvests. In contrast, verbena growth in the compost growing media was significantly increased by the addition of up to $30 \%$ expanded shale for the first harvest, but had little effect on growth for the second harvest. It is likely that expanded shale improved drainage and aeration in the compost, which originally lacked optimal levels of those properties. However, the other three blends of organic materials were already sufficiently porous, thus the addition of expanded shale caused excessive drainage and reduced their ability to retain moisture. Also, for a given greenhouse container volume, replacement of the organic ingredients with expanded shale actually reduced the quantity of nutrients available for plant uptake because expanded shale 
Table 6. Verbena biomass production for two successive harvests of aboveground foliage from four experimental growing media containing $75 \%$ pine bark $(\mathrm{PB})+\mathbf{2 5 \%}$ peatmoss $(\mathrm{PM}), \mathbf{5 0} \% \mathrm{~PB}+\mathbf{5 0} \%$ biosolids $(\mathrm{BS}), \mathbf{1 0 0} \%$ municipal yard waste compost (compost), or $65 \% \mathrm{~PB}+35 \%$ cottonseed hulls $(\mathrm{CH})$ mixed with $0 \%, 15 \%, 30 \%$, or $60 \%$ expanded shale (v/v).

\begin{tabular}{|c|c|c|c|c|c|}
\hline $\begin{array}{l}\text { Expanded shale } \\
\text { content (\%) }\end{array}$ & \multicolumn{4}{|c|}{ First biomass harvest $(\mathrm{g} / \mathrm{pot})^{y}$} & $\mathrm{LSD}^{\mathrm{z}}$ \\
\hline 0 & 23.23 & 25.69 & 17.91 & 9.56 & 2.60 \\
\hline 15 & 21.71 & 22.03 & 19.88 & 7.68 & 2.35 \\
\hline 30 & 20.13 & 21.53 & 21.36 & 7.41 & 2.88 \\
\hline 60 & 17.24 & 20.13 & 19.18 & 8.86 & 2.79 \\
\hline Linear effect ${ }^{\mathrm{x}}$ & ** & $* * *$ & NS & NS & \\
\hline 0 & 11.73 & 14.13 & 8.63 & 9.29 & 1.70 \\
\hline 15 & 10.64 & 9.45 & 10.14 & 6.89 & 1.52 \\
\hline 30 & 10.48 & 9.66 & 9.51 & 6.09 & 1.73 \\
\hline 60 & $8.84 \mathrm{a}$ & 9.38 & 8.84 & 7.56 & 1.37 \\
\hline Linear effect & ** & $* * *$ & NS & $* * *$ & \\
\hline
\end{tabular}

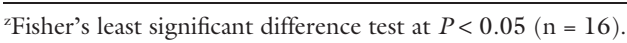

y Aboveground biomass was harvested by clipping plants $5 \mathrm{~cm}(2.0$ inches) above the substrate surface; $1 \mathrm{~g}=0.0353 \mathrm{oz}$.

${ }^{x}$ Linear and quadratic effects of expanded shale content on dependent variables were tested via single-df orthogonal contrasts using PROC GLM of SAS (v. 9.1; SAS Institute, Cary, NC); completely randomized block design $(\mathrm{n}=20)$.

$\mathrm{NS},{ }^{*}, * *,{ }^{* *}$ indicate not significant and significant at the $0.05,0.01$, or 0.001 , level of probability, respectively $(\mathrm{n}=16)$

did not contribute nutrients to the growing medium.

Shantung MAPle. Based on plant height, plant width, and stem thickness (Fig. 2), maple seedlings grew fastest in the $50-\mathrm{PB} / 50-\mathrm{BS}$ blends, followed by the traditional $75-\mathrm{PB} / 25-\mathrm{PM}$ and the compost blends, and finally the $65-\mathrm{PB} / 35$ $\mathrm{CH}$ blends. In general, maple growth reflected the quantity of availability of nutrients in the growing media (Tables 1 and 2). Poor maple growth in the $65-\mathrm{PB} / 35-\mathrm{CH}$ blends might be attributed to nitrogen immobiliza- tion due to a high $\mathrm{C}: \mathrm{N}$ ratio (Table 1), but a poor physical environment for root growth may have been a factor as well because maple growth in the $65-\mathrm{PB} / 35-\mathrm{CH}$ organic matter blend was clearly improved by the addition of expanded shale. Similarly, maple growth in compost was slightly improved by the $60 \%$ addition of expanded shale, probably due to an improved rooting environment as a result of increased drainage and greater aeration.

In the $50-\mathrm{PB} / 50-\mathrm{BS}$ blend of organic materials and the traditional

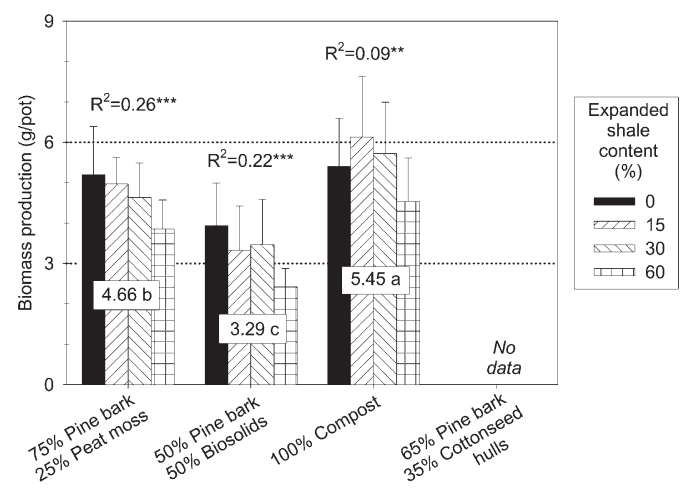

Fig. 1. Vinca aboveground biomass from four organic growing media blended with $0 \%, 15 \%, 30 \%$, or $60 \%$ expanded shale. Correlation coefficients above each cluster indicate the effect of expanded shale on vinca biomass for each organic blend [PROC REG of SAS (v. 9.1; SAS Institute, Cary, NC) at $\alpha=0.05(\mathrm{n}=20)$ ]. Values superimposed on each organic blend are biomass yields averaged over the expanded shale rates. Values followed by the same later are not significantly different [ ${ }^{*}$ and $* * *$ indicated significance at the 0.01 and 0.001 levels of probability, respectively, using Fisher's least significant difference test at $\alpha=0.05(\mathrm{n}=20)] ; 1 \mathrm{~g}=0.0353 \mathrm{oz}$.

75-PB /25-PM blend, maple growth was unaffected by the addition of $15 \%$ and $30 \%$ expanded shale, but was decreased by the addition of $60 \%$ expanded shale, probably due to a reduction in the quantity of plant available nutrients and water. Other researchers have observed decreased plant growth in organic-based growing media as the percentage of expanded slate or shale was increased (Carlile and Bedford, 1988; Nash et al., 1990; Rowe et al., 2006).

\section{Vinca tissue analysis}

Vinca tissue was analyzed for a selected group of nutrients and Table 5 shows the results for the four elements ( N, P, Ca, and $\mathrm{Zn})$ that were most significantly affected by growing media composition. There is no data for the $65-\mathrm{PB} / 35-\mathrm{CH}$ growing mediums because vinca plants failed to grow in the $\mathrm{CH}$ blends. Fertilizer was only added once to all pots at the start of the study, thus later growth was influenced mostly by the inherent fertility of the growing media or the presence of residual fertilizer nutrients. In general, for all the elements analyzed, vinca tissue concentrations were mostly affected by the composition of the organic blends, whereas the amount of expanded shale added to the organic blends was less important.

Nitrogen concentrations were highest in the growing media that 


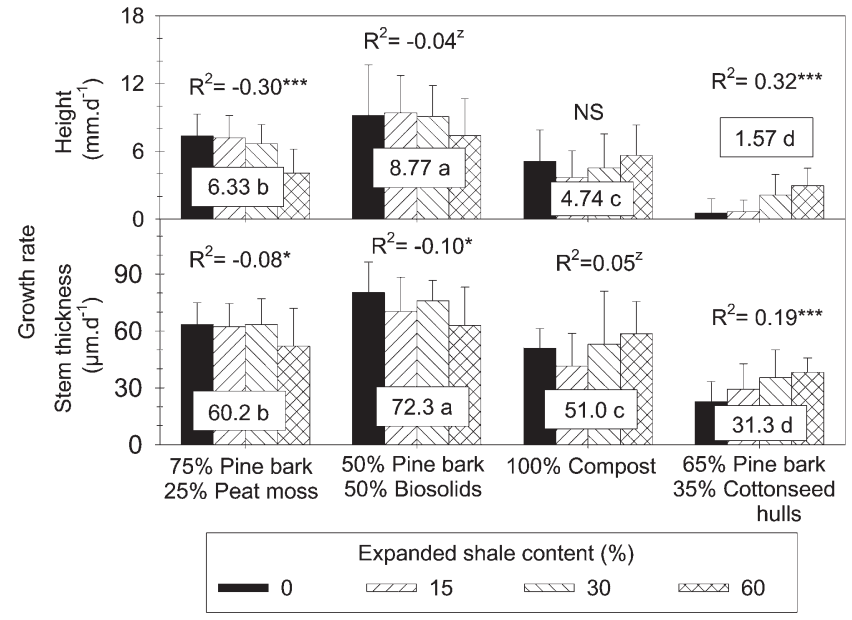

Fig. 2. Growth rate of shantung maple in terms of height (top graph) and stem thickness (bottom graph) for four organic growing media blended with $0 \%, 15 \%$, $30 \%$, or $60 \%$ expanded shale. Correlation coefficients above each organic blend indicate the effect of expanded shale on the rate of increase of height or stem thickness [PROC REG of SAS (v. 9.1; SAS Institute, Cary, NC) at $\alpha=0.05$ $(n=16)]$. Values superimposed on each organic blend are the biomass yields averaged over the expanded shale rates. Values followed by the same letter are not significantly different $\left[?,{ }^{*},{ }^{*}\right.$, and ${ }^{* * *}$ indicate statistical significance at the $0.1,0.05,0.01$ and 0.001 levels of probability, respectively, using Fisher's least significant difference test at $\alpha=0.05(\mathrm{n}=16)] ; 1 \mathrm{~mm}=0.0394$ inch, $1 \mu \mathrm{m}=1$ micron.

contained $50-\mathrm{PB} / 50-\mathrm{BS}$ due to large amounts of total $\mathrm{N}$ and $\mathrm{NO}_{3}-\mathrm{N}$ in the biosolids (Tables 1 and 2). There were no differences in the concentrations of $\mathrm{N}$ in plants grown in the other mixes. There was a slight trend toward reduced $\mathrm{N}$ uptake as the expanded shale content was increased to $60 \%$, but the effect was very small and probably due to a decrease in the quantity of available $\mathrm{N}$ as the expanded shale displaced organic ingredients in the growing media.

Phosphorus uptake by vinca was highest for the growing media that contained 75-PB/25-PM, followed by compost, and finally by $50-\mathrm{PB} /$ 50-BS (Table 5). Phosphorous concentrations in the vinca tissue were inversely related to Ca concentrations (Table 5). Phosphorus availability in soils is significantly reduced by the presence of labile Ca due to the precipitation of Ca-P minerals (Havlin et al., 2005). Lower P uptake in the $50-\mathrm{PB} / 50-\mathrm{BS}$ and compost blends was most likely attributed to higher $\mathrm{Ca}$ concentrations in the growing media. In the case of the $50-\mathrm{PB} / 50$ BS growing media, the source of $\mathrm{Ca}$ was from the BS that had been stabilized with calcium hydroxide $\left[\mathrm{Ca}(\mathrm{OH})_{2}\right]$ during the wastewater treatment process.
Expanded shale tended to decrease $\mathrm{P}$ uptake in the $75-\mathrm{PB} / 25$ $\mathrm{PM}$ growing media, but had no significant effect in the $50-\mathrm{PB} / 50-\mathrm{BS}$ or compost blends. Decrease in $\mathrm{P}$ concentration was due not only to the dilution of available $\mathrm{P}$ in the growing medium by expanded shale, but also due to the ability of expanded shale to adsorb $\mathrm{P}$ and remove it from solution (Forbes et al., 2004; Sloan et al., 2000). Forbes et al. (2004) used the P-absorbing property of expanded shale to remove $\mathrm{P}$ from wastewater effluent in a constructed wetland. Williams and Nelson (2000) also found that pre-fertilized calcined clays were able to provide a reservoir for plant-available $\mathrm{P}$ when blended with a PM/perlite growing medium.

Vinca Ca concentrations were mostly affected by the organic ingredients in the experimental growing media. Calcium uptake was greatest in plants grown in the $50-\mathrm{PB} / 50$ - $\mathrm{BS}$ blends, followed by the compost blends, and then the $75-\mathrm{PB} / 25-\mathrm{PM}$ blends. The BS used in this study had been treated with $\mathrm{Ca}(\mathrm{OH})_{2}$ to raise $\mathrm{pH}$ and kill pathogens (i.e., lime stabilization). Calcium hydroxide is a soluble source of $\mathrm{Ca}$, thus the 50 $\mathrm{PB} / 50$ - $\mathrm{BS}$ growing media contained more plant-available $\mathrm{Ca}$ than the other blends. Expanded shale also contains a significant amount of soluble $\mathrm{Ca}$, and to a lesser extent, $\mathrm{Mg}$ (Sloan et al., 2000). Expanded shale significantly increased vinca $\mathrm{Ca}$ concentrations in the $75-\mathrm{PB} / 25-\mathrm{PM}$ growing media where overall levels of plant-available $\mathrm{Ca}$ were lower (Table 5). Although not statistically significant, there was also a trend for expanded shale to increase $\mathrm{Mg}$ concentrations (data not shown). This suggests that expanded shale can be a significant source of $\mathrm{Ca}$, and possibly $\mathrm{Mg}$, in growing media that contain less than optimal levels of these nutrients.

Vinca plants grown in the 50$\mathrm{PB} / 50$ - $\mathrm{BS}$ growing media had significantly lower $\mathrm{K}$ concentrations than those grown in the other growing media (data not shown). Biosolids tend to be low in $\mathrm{K}$ because wastewater treatment does not remove significant $\mathrm{K}$ from the wastewater stream. Expanded shale had no effect on $\mathrm{K}$ uptake, except for a slight negative correlation $(P=0.07)$ in the compost blends. This is not surprising because $\mathrm{K}$ chemistry is controlled by cation exchange reactions and expanded shale has no significant cation exchange capacity. Williams and Nelson (2000) also observed that calcined clay did not retain sufficient $K$ to supply plant needs when precharged with fertilizer and blended with a PM/perlite blend.

Zinc and $\mathrm{Cu}$ are essential plant nutrients and are also commonly found in composts, BS, and other plant-based materials, although their concentrations in BS are generally higher than in other plant-based organic materials. Therefore, application of these experimental growing media to soil in a landscape setting could have plant nutritional as well as environmental impacts. From a plant nutrition perspective, the concentrations of both these elements in vinca tissues were within the range typically seen in healthy plants (Mengel and Kirkby, 1982). Vinca tissue Zn concentrations were significantly higher for the $50-\mathrm{PB} / 50-\mathrm{BS}$ blends than the 75-PB/25-PM and compost blends (Table 5). There was also a significant reduction in $\mathrm{Zn}$ concentrations with increasing rates of expanded shale for all three basic organic matter blends, and the effect was most pronounced for the $75-\mathrm{PB} / 25-\mathrm{PM}$ growing 
media. Decreases in $\mathrm{Zn}$ concentrations with increasing rates of $\mathrm{ex}^{-}$ panded shale are most likely due to a reduction in the quantity of plant available $\mathrm{Zn}$ due to displacement of the organic ingredients by expanded shale. However, increased $\mathrm{pH}$ with the expanded shale addition was probably another factor that decreased $\mathrm{Zn}$ availability. Expanded shale significantly increased the initial $\mathrm{pH}$ of the blends (Table 2). The final $\mathrm{pH}$ values for the $60 \%$ expanded shale blends were 5.26 for $75-\mathrm{PB} / 25-\mathrm{PM}$, 7.24 for $50-\mathrm{PB} / 50-\mathrm{BS}, 7.56$ for compost, and 6.84 for $65-\mathrm{PB} / 35$ $\mathrm{CH}$ (data not shown). For the more acidic 75-PB/25-PM blend, this represents an increase of more than 1.5 $\mathrm{pH}$ units and as expected, the decrease in vinca tissue $\mathrm{Zn}$ concentrations with increasing expanded shale content was most pronounced in the 75-PB/25-PM blends (Table 5). Vinca tissue concentration of $\mathrm{Cu}$, $\mathrm{Cr}$, and $\mathrm{Ni}$ were unaffected by the three basic blends of organic materials, nor by the amount of expanded shale added to those basic blends (data not shown).

\section{Conclusions}

Growing media composed of locally available compost and BS supported the growth of annual (vinca), perennial (verbena), and woody ornamental (shantung maple) plants as well as or better than a traditional $\mathrm{PB} / \mathrm{PM}$ growing medium. However, fresh $\mathrm{CH}$ were not suitable for use in a growing medium, although evidence suggested they would become suitable after a period of aging. Inclusion of expanded shale in the various growing media produced variable results on plant growth. Expanded shale had positive short-term effects on plant growth when added to growing media that lacked optimum drainage and aeration. This was true of growing media that contained decomposed organic materials such as municipal yard waste compost. Other organic growing media that already contained coarse ingredients, such as $\mathrm{PB}$, performed better without the addition of expanded shale. In general, combining expanded shale with locally obtainable organic ingredients such as BS or municipal yard waste compost can create growing media that perform as well or better than traditional PB plus PM-based growing media.

\section{Literature cited}

American Association of Nurserymen. 1996. American standard for nursery stock. ANSI Z60.1-1996. American Association of Nurserymen, Washington, DC.

Bilderback, T.E., S.L. Warren, J.S. Owen, Jr., and J.P. Albano. 2005. Healthy substrates need physicals too! HortTechnology 15:747-751.

Bremner, J.M. 1996. Nitrogen-total, p. 1085-1121. In: D.L. Sparks, A.A. Adams, and B.B. Baker (eds.). Methods of soil analysis. Part 3. Chemical methods. Soil Sci. Soc. Amer. Book Ser. 5. American Society of Agronomy, Madison, WI.

Bunt, A.C. 1988. Media and mixes for container grown plants: A manual on the preparation and use of growing media for pot plants. Unwin Hyman, London.

Carlile, W.R. and I. Bedford. 1988. Plant growth in container media amended with calcined clay. Acta Hort. 221:117-132.

Fain, G.B., C.H. Gilliam, J.L. Sibley, and C.R. Boyer. 2008. Whole-tree substrate and fertilizer rate in production of greenhouse-grown petunia (Petunia $\times$ bybrida Vilm.) and marigold (Tagetes patula L.). HortScience 43:700-705.

Forbes, M.G., K.R. Dickson, T.D. Golden, P. Hudak, and R.D. Doyle. 2004. Dissolved phosphorus retention of light-weight expanded shale and masonry sand used in subsurface flow treatment wetlands. Environ. Sci. Technol. 38:892898.

Getter, K.L. and D.B. Rowe. 2006. The role of extensive green roofs in sustainable development. HortScience 41:12761285.

Glenn, J. and D. Block. 1999. MSW composting in the United States. Biocycle $40: 42-48$.

Gruda, N., S.V. Toucher, and W.H. Schnitzler. 2000. N-immobilization of wood fiber substrates in the production of tomato transplants (Lycopersicon lycopersicum (L.) Karts. Ex. Farw.). J. Appl. Bot. 74:32-37.

Havlin, J.L., J.D. Beaton, S.L. Tisdale, and W.L. Nelson. 2005. Soil fertility and fertilizers: An introduction to nutrient management, 7th ed. Pearson Education, Upper Saddle River, NJ.
Hernández-Apaolaza, L., A.M. Gascó, J.M. Gascó, and F. Guerrerro. 2005. Reuse of waste materials as growing media for ornamental plants. Bioresour. Technol. 96:125-131.

Jim, C.Y. 1996. Edaphic properties and horticultural applications of some common growing media. Commun. Soil Sci. Plant Anal. 27:2049-2064.

Marble, S.C., C.H. Gilliam, J.L. Sibley, G.B. Fain, H.A. Torbert, and J.W. Olive. 2008. Evaluation of composted poultry, whole tree, and clean chip residual as components of media for container grown nursery woody ornamentals. Proc. Southern Nursery Assn. Res. Conf. 53:7-10.

Mengel, K. and E.A. Kirkby. 1982. Principles of plant nutrition, 3rd ed. International Potash Institute, Worblaufen-Bern, Switzerland.

Nash, M.A., T.P. Brubaker, and B.W. Hipp. 1990. Expanded shale as a potting medium for bedding plants. HortScience 25:1163. (Abstr.).

Olsen, S.R. and L.E. Sommers. 1982. Phosphorus, p. 413-414-421-422. In: A.L. Page, R.H. Miller, and D.R. Keeney (eds.). Methods of soil analysis, Part 2: Chemical and microbiological properties. 2nd ed. Agron. Monogr. No. 9, Amer. Soc. Agron., Soil Sci. Soc. Amer., Madison, WI.

Ozores-Hampton, M. and D.R.A. Peach. 2002. Biosolids in vegetable production systems. HortTechnology 12:336-340.

Rowe, D.B., M.A. Monterusso, and C.L. Rugh. 2006. Assessment of heatexpanded slate and fertility requirements in green roof substrates. HortTechnology 16:471-477.

Sloan, J.J., S.W. George, W.A. Mackay, P. Colbaugh, and S. Feagley. 2002. The suitability of expanded shale as an amendment for clay soils. HortTechnology 12:646-651.

Sloan, J.J., W.A. Mackay, and S.W. George. 2000. Growing mediums for porous pavement and rooftop gardens. First Annu. Conf. Soils of Urban, Industrial, Traffic, and Mining Areas. Essen, Germany, 12-18 July 2000, p. 321-327.

Steuteville, R. 1996. How much does it cost to compost yard trimmings? Biocycle 37:39-46.

Williams, K.A. and P.V. Nelson. 2000. Phosphate and potassium retention and release during Chrysanthemum production from precharged materials: II. Calcined clays and brick chips. J. Amer. Soc. Hort. Sci. 125:757-764. 